\title{
"JEGO ANTYCYPACJA PIECZOLOWICIE ZAPLANOWANEGO ŻYCIA PO KATASTROFIE DOWODZI POSIADANIA PERSPEKTYWY"1 - TOPONIMY W POWIEŚCI GÜNTERA GRASSA DIE RÄTTIN JAKO PROBLEM PRZEKŁADOZNAWCZY I LITERATUROZNAWCZY
}

\author{
JoANnA KuBASZCZYK ${ }^{2}$ \\ (Uniwersytet im. Adama Mickiewicza w Poznaniu)
}

\begin{abstract}
Słowa kluczowe: przekład toponimów, przekład literacki, pielęgnowanie pamięci, punkt widzenia, utracona ojczyzna, projekt przyszłości Keywords: translation of toponyms, literary translation, memory work, point of view, lost homeland, future project
\end{abstract}

\begin{abstract}
Abstrakt: Joanna Kubaszczyk, "JEGO ANTYCYPACJA PIECZOŁOWICIE ZAPLANOWANEGO ŻYCIA PO KATASTROFIE DOWODZI POSIADANIA PERSPEKTYWY" - TOPONIMY W POWIEŚCI GÜNTERA GRASSA DIE RÄTTIN JAKO PROBLEM PRZEKŁADOZNAWCZY I LITERATUROZNAWCZY. „PORÓWNANIA” 1 (22), 2018. T. XXII, S. 199-218. ISSN 1733-165X. Powieść Güntera Grassa Die Rättin to wielowątkowe dzieło splatające refleksje na temat przeszłości, teraźniejszości i przyszłości, realizm z baśniowością i mitem. Szczególną rolę w powieści odgrywa antyutopijny projekt przyszłości. W artykule autorka, analizując funkcje i przekład toponimów w powieści Grassa i jej przekładzie na język polski Sławomira Błauta, zastanawia się, na ile ów projekt przyszłości jest tożsamy w oryginale i przekładzie oraz czy strategia przekładu nazw
\end{abstract}

1 Mój przekład zdania: „Ihr Vorgriff auf fürsorglich geplantes Nachleben beweist Perspektive“ (Grass 1999: 443). W przekładzie Błauta fragment ten brzmi: „Jego antycypacja starannie zaplanowanego życia to coś, co ma perspektywę" (Grass 2001: 378).

2 E-mail: gluck@amu.edu.pl 
własnych obrana przez tłumacza jest strategią słuszną, na ile zaś przekład gubi wielość odniesień i skomplikowaną kreację autorską o mieście o podwójnej tożsamości.

Abstract: Joanna Kubaszczyk, "HIS ANTICIPATION OF A CAREFULLY PLANNED LIFE AFTER THE CATASTROPHE PROVES HAVING A PERSPECTIVE" - TOPONYMS IN GÜNTER GRASS'S NOVEL DIE RÄTTIN AS A TRANSLATION AND LITERARY THEORY PROBLEM. “PORÓWNANIA" 1 (22), 2018. Vol. XXII, P. 199-218. ISSN 1733-165X. Grass's novel Die Rättin is a multi-faceted piece of work reflecting on the past, present and future, combining realism with fairy tales and myth. The anti-utopian project of the future plays a special role in the novel. In the article, the author analyzes the functions and translations of toponyms in Grass's novel and its Polish translation by Błaut examining how far the project of the future is identical in the original and translation and whether the translation strategy of toponyms selected by the translator is a correct strategy or whether it leads to the loss of multiple references and it destroys the author's complicated creation of a city with a double identity.

\section{Wstęp}

Günter Grass opublikował powieść apokaliptyczną Die Rättin w roku 1986. Polskiego przekładu, który ukazał się w roku 1993 pod tytułem Szczurzyca, dokonał Sławomir Błaut.

To wielowątkowe dzieło łączy w sobie cechy różnych gatunków literackich, takich jak bajka i baśń, fantastyka, (anty)utopia, powieść surrealistyczna, splata elementy reportażu, scenariusza filmowego, przeplatane jest krótkimi wierszami. Zawiera intertekstualne nawiązania, między innymi do Baśni braci Grimm, Biblii, do wcześniejszych powieści Grassa, jak Blechtrommel (Blaszany bębenek) czy Der Butt (Turbot), oraz wątki autobiograficzne (por. Gruettner).

W powieści Grassa przeplatają się różne porządki czasowe i miejsca akcji, między którymi porusza się narrator zamknięty w kapsule kosmicznej krążącej wokół Ziemi. Ważne miejsca akcji to Lubeka, Gdańsk (względnie Danzig) i tereny otaczające miasto, Morze Bałtyckie, Baśniowy Las. Jako kulisy pojawiają się Niemcy Zachodnie i Wschodnie, jest też wiele odniesień globalnych do różnych miejsc na kuli ziemskiej.

Jeżeli chodzi o porządki czasowe i chronologię wydarzeń, to poza wątkiem baśniowym, który istnieje z natury rzeczy poza czasem, ale wpisuje się też poniekąd w powieściową teraźniejszość powojennych, jeszcze podzielonych $\mathrm{Niemiec}^{3}$, w powieści występują odniesienia do legendarnej historii wczesnego średniowiecza, do okresu przedwojennego, II wojny światowej, lat pięćdziesiątych oraz do lat osiemdziesiątych. Czasem akcji jest też czas poludzki, postczłowieczy, przyszłość po katastrofie. W stanowiącym element świata przedstawionego filmie Matzerata jawi się

3 Kryzys w Bonn jako element wyzwalający akcję baśniowych bohaterów, por.: „In Bonn, die spielen bestimmt verrückt. Notstand und so!“ (Grass 1999: 333). 
jeszcze jedna perspektywa, niczym czas zaprzyszły: „temat przejścia postczłowieczej historii w neoczłowieczą" (Grass 2001: 378). Rozróżnienie przynajmniej trzech przedziałów czasowych, a mianowicie okresu do końca II wojny światowej, okresu powojennego aż po czasy współczesne narratora, czyli do połowy lat osiemdziesiątych $\mathrm{XX}$ wieku, i okresu postczłowieczego jest istotne dla sposobu interpretacji i przekładu używanych przez Grassa toponimów.

Jako że historia Polski i Niemiec, do której odwołuje się Grass, jest zasadniczo znana, zatrzymam się krótko tylko przy wizji postczłowieczej przyszłości. W fantasmagorii Grassa tereny aglomeracji, którą nazywa Danzig-Gdańsk zamieszkują trzy różne grupy szczurów:

Grob unterschieden, zeichnen sich drei Konfessionen ab, wobei die Herkunft unserer Rattenvölker eine gewisse Rolle spielen mag: Wir sind in dieser Region alteingesessene Ratten, dann gibt es solche, die kurz vorm Großen Knall über die sogenannte Landrattenbrücke aus dem Westen zuwanderten, und solche, die kürzlich aus der Weite des russischen Raumes einsickerten; dabei sind alle drei Völker in ihrem Wesen und bis ins Zinkgrüne ihrer posthumanen Behaarung nicht grundsätzlich verschieden, nur frömmeln sie widersprüchlich... (Grass 1999: 296)

Z grubsza rzecz biorąc, zaznaczają się trzy wyznania, przy czym pewną rolę odgrywa chyba pochodzenie naszych szczurzych ludów: My jesteśmy szczurami osiadłymi w tym rejonie od dawna, potem są takie, które na krótko przed wielkim Bum-Bum przywędrowały z zachodu tak zwanym szczurzym mostem, i takie, które przeniknęły niedawno $\mathrm{z}$ rozległych rosyjskich przestrzeni; przy tym między wszystkimi trzema ludami $\mathrm{w}$ ich naturze i aż po cynkową zieleń ich postczłowieczego uwłosienia nie ma zasadniczych różnic, sprzeczności występują tylko w nabożności... (Grass 2001: 254).

Nietrudno rozpoznać, że szczury z terenów Rosji symbolizują Polaków przymusowo wysiedlonych z Kresów, druga grupa to rdzenni mieszkańcy, którzy mieszkali na opisywanych terenach "od zawsze". Trzecia grupa przedstawia alegorycznie Niemców. Jak się znaleźli w Gdańsku? Odpowiedź pada między innymi w poniższym fragmencie:

Przed zakopaniem się przemieściłyśmy nasz przychówek, wycofując się z obszaru pierwszego rażenia, choćby z terenów nad Renem i Menem, skupisk w Saksonii, baz w Szwabii. [...] A że w Polsce znowu występowały braki i potrzebna była pomoc [...] postarałyśmy się o żywność z zachodniego nadmiaru, tak że ludziom i szczurom w Polsce wkrótce mniej brakowało; ponadto wraz z ziemiopłodami udało się przerzucić zagrożone populacje: stada szczurów z zagłębia Ruhry [...] (Grass 2001: 89)4.

4 We wszystkich cytatach z Grassa wytłuszczenia oraz podkreślenia pochodzą od autorki artykułu. 
A zatem na poziomie projektu przyszłości, bajki o szczurach, odbywa się swoista niemiecka rekolonizacja Gdańska. Znajduje to swoje odbicie również w toponimach używanych w powieści, co szczegółowo omówię w dalszej części artykułu. Owo ponowne zasiedlenie wiąże się ze stopniową germanizacją szczurzych stad, która odzwierciedla się w zmianach zachodzących w języku (por. Grass 2001: 313-314), w stosunkach religijnych (por. „Nicht mehr dürfen die Katholischen das letzte Wort haben”, Grass 1999: 444-445; „katolicy nie mogą już mieć ostatniego słowa”, Grass 2001: 379), itp.

\section{Toponimy i ich przekład - podstawowe założenia}

Toponimy to inaczej nazwy miejsc. Zalicza się do nich m.in. nazwy państw, miejscowości, gór czy wód, nazwy ulic i placów, pól i lasów, nazwy fizjograficzne, mikrotoponimy itp.

Zanim zajmę się szczegółowo kwestią toponimów w powieści Grassa i ich przekładem, krótko przedstawię kilka podstawowych założeń, które są istotne dla dalszego wywodu.

Uznaje się, że toponimy, jak i pozostałe nazwy własne, nie są znaczeniowo puste, mimo iż nie posiadają znaczenia leksykalnego $\mathrm{w}$ takim sensie, $\mathrm{w}$ jakim posiadają je nazwy pospolite (Gajda 24, Czerny 245-246). Za Stanisławem Gajdą przyjmuję, że „poznanie realnego sensu nazwy własnej zależy od znajomości kontekstu, tła onimicznego" (Gajda 24). Po drugie zakładam, że choć część nazw własnych posiada warianty onimiczne, to nie są one $\mathrm{w}$ pełni równoważne znaczeniowo i wymienne, wprowadzają bowiem odmienne konotacje lub wynikają z innego punktu widzenia ${ }^{5}$. Po trzecie, znaczenie nazwy własnej w tekście wiąże się ściśle z funkcją, jaką ona w nim pełni, zaś od funkcji proprium w tekście zależy metoda (technika) przekładu (por. np. Hejwowski). Na przekład toponimów ma ponadto wpływ szereg innych czynników jak kontekst oraz rodzaj i gatunek tekstu, w którym dany toponim się pojawia, realność bądź fikcyjność nazwy, punkt widzenia, którego nazwa jest wykładnikiem, czy związki intertekstualne.

5 Dla wielu nazw fakt ten jest opisany, np. w przypadku pary Jeruzalem - Jerozolima. Obie nazwy są nacechowane - na co wskazuje Bogdan Burdziej (Burdziej 25) - nieco odmiennie znaczeniowo i stylistycznie. Jeruzalem konotuje według Burdzieja dostojeństwo i nobliwość, której to konotacji nie posiada w takim stopniu nazwa Jerozolima. Podobnie, zupełnie inne konotacje mają Auschwitz i Oświęcim czy nawet Warszawa i Warschau. Porusza tę kwestię m.in. Jerzy Ziomek, który słusznie wskazuje, że w przekładzie mogą wystąpić sytuacje, gdy „względy historyczne czy polityczne każą poprawną transliterację zastąpić błędną pożyczką" (Ziomek 186), i podaje za przykład komunikat radiowy „Hier spricht Warszawa” zamiast „Hier spricht Warschau” w latach powojennych. 


\section{Między przeszłością a przyszłością: Die Rättin Güntera Grassa}

Pośród funkcji, jakie mogą pełnić nazwy własne, Gajda wymienia funkcję wychowawczą oraz patriotyczną (Gajda 27). Funkcje te można by zakwalifikować jako edukacyjno-społeczne. Dalej badacz wskazuje również funkcję kumulacyjną oraz poznawczą (Gajda 27). Które ze wskazanego przez autora repertuaru można przypisać toponimom $\mathrm{w}$ apokaliptycznej antyutopii niemieckiego noblisty? W powieści Die Rättin, jak i w kilku wcześniejszych, Grass umieszcza zdarzenia w świecie, którego już nie ma, a pozostał w pamięci osób, które spędziły w nim swoje dzieciństwo i młodość, jako świat obrazów i nazw: nazw osób, ulic, dzielnic, zaułków, miejscowości podmiejskich. Jednak wspomnienia mają to do siebie, że się zacierają. Świat już nieistniejący trzeba komuś opowiedzieć, by nie popadł w niepamięć, w niebyt. Ten właśnie aspekt pielęgnowania pamięci, tzw. „pracy pamięci” (niem. Erinnerungsarbeit) jest, jak się wydaje, jedną z motywacji pisarstwa Grassa. Zwraca na niego uwagę Bernadette Conrad, pisząc:

Günter Grass war es ja schon vor 50 Jahren um das Verlorene gegangen. Die Blechtrom$m e l$, sagte er einmal, sei sein »Versuch, ein Stück endgültig verlorene Heimat festzuhalten«. Als er in den letzten Oktobertagen 1958 das erste und das 34. Kapitel seines Romans der Gruppe 47 vorlas, hatte er mit Hilfe von Oskars rot-weißem Blech schon ein großes Stück Heimatlandschaft herangetrommelt (Conrad).

Już 50 lat temu Günterowi Grassowi chodziło o to, co utracone. Powiedział kiedyś, że Die Blechtrommel [Blaszany Bębenek] to jego „próba zatrzymania cząstki definitywnie utraconej ojczyzny". Kiedy pod koniec października 1958 roku prezentował pierwszy i 34 rozdział swej powieści grupie 47, z pomocą czerwono-białej blachy Oskara udało mu się przybębnić całkiem spory fragment ojczystego krajobrazu (tłum. J.K.).

Również Die Rättin należy uznać za taką próbę zachowania w pamięci, uwiecznienia utraconej ojczyzny. Używając toponimów związanych z niemiecką historią Gdańska i okolic, autor szczurzej antyutopii tworzy bowiem ,językowy obraz konkretnej rzeczywistości, wpisanej w przestrzeń" (Makarski 1). Czy jednak w powieści tej Grass traktuje swą ojczyznę jako definitywnie utraconą (,endgültig verloren")? Jak już pokazywałam we wstępie, niekoniecznie. Jego apokaliptyczna wizja przyszłości zawiera przecież projekcję czy może nawet projekt przyszłości, projekt powrotu i utopijną wizję mniej lub bardziej harmonijnego współżycia.

We fragmencie powieści dotyczącym pochodzenia Malskata padają słowa o coraz bardziej kruchych wspomnieniach świata, którego albo już nie ma, albo nosi inną nazwę:

Im Jahr 1913 wurde unser Maler in der ostpreußischen Stadt Königsberg am Fluß Pregel geboren. [...] Die Familie Malskat - so hieß der Vater unseres Malers - wohnte in König- 
sergs Flinsenwinkel. Der Fluß Pregel floß ins Frische Haff, dass sich bei Pillau zur Ostsee öffnete. Heute heißt Königsberg Kaliningrad, und auch der Fluß heißt anders. Den Flinsenwinkel gibt es nicht mehr. Nur immer brüchiger werdende Erinnerungen gibt es, außerdem Bücher, die der sein Lebtag in Königsberg ansässige Philosoph Immanuel Kant vergeblich geschrieben hat [...] (Grass 1999: 105-106).

W roku 1913 urodził się nasz malarz we wschodniopruskim mieście Królewcu nad rzeką Pregołą. [...] Rodzina Malskatów - tak nazywał się ojciec naszego malarza - mieszkała w królewieckim Flinsenwinkel. Rzeka Pregoła wpływała do Zalewu Wiślanego, który pod Piławą łączył się z Morzem Bałtyckim. Dzisiaj Królewiec nazywa się Kaliningrad, a i rzeka nosi inne miano. Nie ma już Flinsenwinkel. Są tylko coraz bardziej kruche wspomnienia, poza tym książki, które osiadły przez całe życie w Królewcu filozof Immanuel Kant napisał daremnie [...] (Grass 2001: 92).

Można zatem założyć, że jedną z funkcji toponimów w powieściach Grassa jest właśnie funkcja edukacyjno-memoryzacyjna, że pisarz przypomina popadające w zapomnienie nazwy, które dla młodego pokolenia Niemców stały się nieoczywiste, że uczy historyczno-sentymentalnej topografii. W tym kontekście pytanie o nazwy własne w utworze nabiera nowego znaczenia, nazewnictwo bowiem - jak trafnie sformułował to polski publicysta Piotr Cywiński - ,jest najkrótszą i najszybciej zapadającą w pamięć lekcją historii..." (Cywiński).

Zanim spróbuję odpowiedzieć na pytanie, jak należałoby tłumaczyć toponimy w utworach Grassa (o ile jakakolwiek jednoznaczna odpowiedź jest możliwa), chcę zapytać, jakiej historii uczy Grass i jak wygląda jego projekt przyszłości, gdyż historia zawsze rzutuje na teraźniejszość i na przyszłość. W tym celu poddam analizie różne użycia nazw własnych w omawianym utworze.

\section{Nazwy własne w Die Rättin}

Jednym z wyżej przedstawionych założeń jest twierdzenie, że warianty onimiczne mogą sygnalizować odmienne punkty widzenia. Od punktu widzenia może - w dwojakim sensie - zależeć również tłumaczenie nazw własnych. Twórca przekładu może bowiem dążyć do zachowania perspektywy autora, może jednak również w subtelny sposób - ze względu na własny punkt widzenia (lub punkt widzenia instytucji, która go finansuje itp.) - tę perspektywę zmienić, wybierając odpowiedni wariant onimiczny.

Stąd w sytuacji przekładu oraz krytyki przekładu trzeba ustalić najpierw punkt widzenia autora tekstu. Jak da się go zrekonstruować na podstawie użyć nazw własnych w powieści Die Rättin? Sprawę komplikuje w tym wypadku fakt, iż narracja osnuta jest wokół stosunków polsko-niemieckich. Mnogość perspek- 
tyw sprawia, że nazwy występujące w powieści możemy podzielić na kilka różnych grup.

Po pierwsze mamy punkt widzenia zewnętrzny, neutralny, reprezentowany przez nazwy neutralne z perspektywy zarówno polskiej, jak i niemieckiej, przynajmniej w kontekście omawianego dzieła. Do tej grupy należą takie nazwy jak Moskau, Washington (Grass 1999: 82), Bangladesh, Türkei, Tokio, Stockholm, Sidney, Montreal (Grass 1999: 83), Soho, Rio, Rom, Brüssel (Grass 1999: 84), Grønsund, Møns (Grass 1999: 95), Møns Klint, Stege, Bogø (Grass 1999: 96), Genf (Grass 1999: 217), Libau, Tsushima (Grass 1999: 218) - odpowiednio w polskim tłumaczeniu: Moskwa', Waszyngton, Bangladesz (Grass 2001: 73), Turcja, Tokio, Sztokholm, Sydney, Montreal, Soho, Rio, Rzym, Bruksela (Grass 2001: 74), Grønsund, Møns Klint, Stege, Bogø (Grass 2001: 84), Genewa (Grass 2001: 188), Lipawa, Cuszima (Grass 2001: 189). Nazwy te są różnego typu - są wśród nich endonimy i egzonimy. Część nazw dostosowana jest do systemu języka docelowego wyłącznie poprzez ułatwiającą wymowę grafię (Sztokholm), rzadziej używane toponimy zachowały pisownię oryginalną (por. inne nazwy szwedzkie).

Po drugie, w dziele występują niemieckie endonimy. Są to również nazwy neutralne w kontekście powieści, odnoszące się do terenów dzisiejszych Niemiec i czasów współczesnych: Hameln (Grass 1999: 61) - Hameln (Grass 2001: 54), Kieler Förde, Ostholstein (Grass 1999: 62) - Kieler Förde, wschodni Holsztyn (Grass 2001: 55), Lübeck (Grass 1999: 371) - Lubeka (Grass 2001: 317), Schleswig (Grass 1999: 372) - Szlezwik (Grass 2001: 318), Schlei (Grass 1999: 372) - Schlei (Grass 2001:318), Oder, Braunschweig, Hannover (Grass 1999: 360) - Odra, Brunszwik, Hanower (Grass 2001: 308), Helmstedt (Grass 1999: 361) - Helmstedt (Grass 2001: 308). W poniższym fragmencie pojawiają się nazwy z terenów zarówno wschodnich, jak i zachodnich Niemiec:

Ich schlage Bamberg und Dresden als zu neutronisierende Städte vor [...]. Es können, ohne daß ich mich festlegen will, hier Rothenburg ob der Tauber, drüben Stralsund folgen, dann Lübeck und Bautzen. [...] Und was ist mit Celle? Oder: Warum nicht Bayreuth? [...] Aber sie wird auch lernen müssen, nein zu sagen, sobald der einen oder anderen Stadt, heiße sie nun Leipzig oder Stuttgart, Magdeburg oder Frankfurt am Main, die herkömmliche Zielzuweisung erhalten bleiben muß (Grass 1999: 237).

[...] ja proponuję Bamberg i Drezno jako miasta do neutronizacji [...]. Nie chciałbym się wiązać, ale w dalszej kolejności mogłyby pójść tutaj Rothenburg nad Tauber, tam Stralsund, potem Lubeka i Budziszyn. [...] A co z Celle? albo: Dlaczego nie Bayreuth?[...] Ale będzie też musiała się nauczyć mówić: nie, kiedy to lub inne miasto, niech się nazywa Lipsk albo Stuttgart, Magdeburg albo Frankfurt nad Menem, pozostanie z konieczności celem tradycyjnym (Grass 2001: 205).

6 Nazwy podaję w mianowniku niezależnie od przypadka, w jakim występują w tekście. 
Obojętnie, czy mowa o nazwach krajów, miast, rzek czy regionów, strategia tłumacza jest zasadniczo jedna. Jeśli to możliwe, czyli wtedy, gdy istnieją i są stosowane polskie egzonimy, Błaut stara się ich używać, choć nie zawsze jest w tym w pełni konsekwentny ${ }^{7}$. W pozostałych przypadkach, gdy egzonim nie istnieje albo istnieje wyłącznie jako nazwa historyczna, tłumacz stosuje niemieckie endonimy. Nie kreuje on w ten sposób jakiegoś specyficznie polskiego punktu widzenia. Egzonimy, którymi się posługuje, są od wieków w użyciu i można je uznać za neutralne.

W kontekście niemieckim pojawiają się też hodonimy, nazwy dzielnic i nazwy obiektów. Warto zwrócić uwagę, że hodonimów odnoszących się do współczesnych Niemiec Błaut nie tłumaczy:

[...] szczurze stada ciągną o tej samej porze głównymi ulicami; jeśli po tamtej stronie za odpowiednią uważają Frankfurter Allee, to tutaj Kurfürstendamm, od kościoła Pamięci po Halensee, jest dla nich dostatecznie długa (Grass 2001: 72).

Jako osobną grupę należy wyodrębnić niemieckie endonimy odnoszące się do Niemiec podzielonych po II wojnie światowej, istniejących w formie dwupaństwowej jeszcze w czasie rozgrywania się fabuły powieści. Chodzi tu o nazwy specyficznie związane z tym okresem: von Ost- nach Westberlin (Grass 1999: 83) - ze wschodniego do zachodniego Berlina (Grass 2001: 74), DDR (Grass 1999: 95) - NRD (Grass 2001: 83). Należy uznać je zasadniczo również za neutralne.

Ponadto można wyróżnić trzecią grupę nazw, które odnoszą się do wspó1czesnej Polski. Wśród nich pierwsza grupa to niemieckie egzonimy będące nazwami polskich miast, które albo nigdy nie były, albo były krótko pod administracją pruską jak Krakau, Warschau (Grass 1999: 238) - Kraków, Warszawa (Grass 2001: 205).

Podobnie jak polskie egzonimy niemieckich miast, regionów czy rzek są one od wieków w użyciu i można je uznać za neutralne. Tłumacz zgodnie ze swoją strategią oddaje je za pomocą polskich endonimów. W tym wypadku jest to postępowanie jak najbardziej uzasadnione.

W powieści występują również nazwy polskie (endonimy) odnoszące się do powojennego, względnie postludzkiego Gdańska oraz okolic (Prus Wschodnich), reprezentujące neutralny punkt widzenia. Przykładem jest opis katastroficznego filmu Matzeratha, w którym pojawia się obok innych miast świata również polska nazwa Gdańsk:

Man mag nicht aufzählen, was des Herrn Matzerath Videokunst im Vorgriff hinwegrafft, einebnet, zu Kraterlandschaften wandelt oder in Sonderfällen, wo Kulturgut ge-

7 Wyjątki w tej strategii omawiam w innym miejscu (Kubaszczyk 134-136).

8 Za taki krótki i stosunkowo nieznaczący okres uznaję pruską administrację w Warszawie w latach 1795-1807. Na negatywne konotacje nazwy Warschau dużo silniej wpłynął okres okupacji 19391945, na co wskazywałam pośrednio w przypisie 4. 
schont werden durfte, als Kulisse erhält, Florenz etwa, Kyoto und - wie wir wissen Gdańsk (Grass 1999: 443).

Nie sposób wyliczyć, co sztuka video pana Matzeratha zmiata, zrównuje z ziemią, zamienia w księżycowy kraj obraz [sic!] lub w specjalnych wypadkach, kiedy chodziło o oszczędzenie dóbr kultury, zachowuje jako dekorację, choćby Florencję, Kioto i - jak wiemy - Gdańsk (Grass 2001: 377).

Obok tego rodzaju użyć nazw, które można uznać za neutralne, mamy w Die Rättin nazwy polskie odnoszące się do powojennego Gdańska, reprezentujące wyraźnie polski punkt widzenia. W poniższym fragmencie taką interpretację uzasadnia dopowiedzenie, że to Polacy nazwali w ten sposób Hopfengasse: „Gedränge auf den Kaianlagen und auf der Chmielna, wie die Polen die Hopfengasse genannt haben” (Grass 1999: 434); "Ścisk na bulwarach i na Chmielnej” (Grass 2001: 370).

W przekładzie brakuje tej informacji. We fragmencie tym widzimy sposób postępowania tłumacza, który regularnie usuwa z tekstu odniesienia do historycznych zmian w obrębie miasta i regionu bądź do ich podwójnej tożsamości. W przekładzie pozostaje wyłącznie polski punkt widzenia. „Tej pamięci nie chcemy pielęgnować”, mogłoby brzmieć ukryte motto przekładu.

W powieści występują też nazwy niemieckie terenów otaczających Gdańsk w wątku Matzerata, rozgrywającym się w połowie lat osiemdziesiątych. Można założyć, że nazwy mają przede wszystkim ułatwić czytelnikowi niemieckiemu identyfikację opisywanych miejsc, a także stanowią intertekstualne nawiązanie do wcześniejszych powieści trylogii gdańskiej (wątek Anny Koljaiczkowej, obchodzącej 107 urodziny): "Aus Kaschemken und Kokoschken, von überall kommen Eier zusammen” (Grass 1999: 99); „Z Karczemek i Kokoszek, zewsząd nadchodzą jajka” (Grass 2001: 87).

Ponieważ główną funkcją jest tu funkcja identyfikacyjno-lokalizująca i aluzyjna, należy uznać, że przekład realizuje je odpowiednio, tym bardziej że chodzi o czas powojenny.

Kolejną grupą są nazwy polskie obowiązujące obecnie oraz nazwy niemieckie obowiązujące podczas zaborów. Przynależne tu nazewnictwo dotyczy rdzennie i bezspornie polskich miast, takich jak Poznań i Bydgoszcz. Poznań znalazł się pod panowaniem pruskim na skutek II rozbioru i był pod nim do końca grudnia 1918 roku, Bydgoszcz leżała w granicach państwa pruskiego od I rozbioru w 1772 roku do roku 1920. Okres ten był przerwany krótką przynależnością obu miast do Księstwa Warszawskiego (1806-1815). O ile Poznania mimo silnych tendencji germanizacyjnych podczas zaborów raczej nikt poważnie nie traktuje jako niemieckiego miasta, to w Bydgoszczy do końca II wojny światowej żyli jeszcze Niemcy, choć repolonizacja miasta nastąpiła w okresie międzywojnia bardzo szybko. W Niemczech żyje do dziś wiele osób tam urodzonych. W tym kontekście wzmianka Grassa na 
temat Bydgoszczy, „,która wcześniej nazywała się Bromberg”, nabiera specyficznego wydźwięku, nie chodzi tu bowiem jedynie, jak się wydaje, o zestawienie endonimu z egzonimem w celu lepszej identyfikacji, lecz o pewne roszczenie: „Es reist also nicht nur über Poznan und Bydgoszcz, das früher Bromberg hieß, unser Herr Matzerath an [...]” (Grass 1999: 209); „Przyjeżdża zatem nie tylko, przez Poznań i Bydgoszcz, nasz pan Matzerath [...]" (Grass 2001: 182).

W przekładzie nazewnicze odniesienie do historii Bydgoszczy znowu znika, $\mathrm{w}$ związku z czym czytelnik polski pozbawiony jest również informacji o owym roszczeniu. Co więcej, po wprowadzeniu polskich nazw, nieco dalej Grass używa już tylko nazw niemieckich, w przekładzie jednak konsekwentnie pojawiają się wyłącznie nazwy polskie: „Während er im lädierten Mercedes unterwegs ist und sich, nach traumloser Übernachtung, von Posen her Bromberg nähert, müssen nun andere Fragen, wenn nicht ihm, dann rhetorisch gestellt werden [...]" (Grass 1999: 211); „Podczas gdy on jedzie obtłuczonym mercedesem i, po noclegu bez snów, z Poznania zbliża się do Bydgoszczy, trzeba postawić, jeśli nie jemu, to retorycznie, inne pytania [...]" (Grass 2001: 183). W ten sposób w przekładzie kolejny raz dochodzi do zmiany punktu widzenia.

Następna grupa toponimów to nazwy historyczne odnoszące się do określonego okresu historycznego. W powieści mamy odniesienia do różnych epok. Do okresu średniowiecza nawiązują częściowo legendarne nazwy Jumne, Vineta, Jomsburg. Pojawiają się one w kontekście wyprawy morskiej Damroki i jej towarzyszek:

$\mathrm{Zu}$ fünft hocken, sitzen, stehen sie hinterm Steuerhaus unter fast geschwundenem Mond und hören Damroka zu, die [...], von der wendischen Siedlung Jumne erzählt, die später, nachdem sie von Wikingern und Dänen zerstört worden war, wiederaufgebaut und Vineta genannt wurde. Anfangs stand neben dem Fischerdorf Jumne, das sich zur Stadt auswuchs, die Jomsburg als Zuflucht der Wikinger (Grass 1999: 281).

W piątkę kucają, siedzą, stoją za sterówką pod prawie zanikłym księżycem i słuchają Damroki, która [...] opowiada o wenedzkim osiedlu Jumne, zniszczonym przez Wikingów i Duńczyków, a później odbudowanym i nazwanym Winetą. Początkowo koło wioski rybackiej Jumne, która rozrosła się w miasto, stał zamek Jomsburg, ostoja Wikingów (Grass 2001: 241).

Osadę Jumne opisywał Adam z Bremy. Prawdopodobnie wspomniał też wtedy o Jomsborgu - tak brzmi spolszczona nazwa tej miejscowości - legendarnej osadzie wikingów, która pojawia się w sagach skandynawskich i w XII- oraz XIII-wiecznych źródłach historycznych. Motywem założenia osady miała być wedle źródeł ekspansja na tereny słowiańskie i najazdy na Słowian. Sagi głoszą, że Jomsborg był nie tylko fortecą, ale także rozległym miastem posiadającym spory port. Encyklopedia PWN podaje, że nazwy Jumne, Wineta oraz Jomsborg odnoszą się do dzisiejszego Wolina (Wolin). 
W tym wypadku widzimy, że w przekładzie zmienia się punkt widzenia na skutek tego, że tłumacz zachował niemiecką nazwę osady-twierdzy. Ponieważ istnieje nazwa spolszczona, a tłumacz jej nie użył, choć - jak powiedziałam powyżej stosuje strategię używania nazw polskich, w sposób najprawdopodobniej nieświadomy, wynikający zapewne z niewystarczająco dokładnej kwerendy, podkreślił niemiecki punkt widzenia. Ponadto, wprowadzając do tekstu eksplikację (zamek), zawęził znaczenie toponimu, który był nazwą nie tylko fortecy, lecz miasta. Oczywiście można by też argumentować, że w ten sposób Błaut jednocześnie wydobył znaczenie członu -burg w złożeniu Jomsburg dla polskojęzycznego odbiorcy.

W tekście pojawiają się też nazwy historyczne, które reprezentują określony punkt widzenia bez wpływu na świat przedstawiony w powieści. Taką nazwą jest Tannenberg jako miejsce bitwy. Ponieważ bitwę tę określa się w polskiej historiografii jako bitwę pod Grunwaldem, decyzja tłumacza, by użyć utrwalonej w świadomości ogółu Polaków nazwy, jest tu jak najbardziej uzasadniona, tym bardziej że nazwa niemiecka nie została tu użyta kontrowersyjnie, a jej zastosowanie w przekładzie utrudniłoby odbiorcy polskiemu identyfikację i lokalizację: „Sie erzählte ihren Nestratten von Ordensrittern und wie fett man sich auf dem Schlachtfeld von Tannenberg gemacht habe” (Grass 1999: 103); „Opowiedziała swoim małym o Krzyżakach i jak to się utuczono na polu bitwy pod Grunwaldem" (Grass 2001: 90).

Wiele nazw odnosi się do okresu przed II wojną światową. W tym wypadku chodzi głównie o toponimy z terenów ówczesnych Prus Wschodnich, choć nie tylko. Jako przykład można przywołać cytowany wcześniej fragment, mówiący o pochodzeniu Malskata i mieście Kanta: „Im Jahr 1913 wurde unser Maler in der ostpreußischen Stadt Königsberg am Fluß Pregel geboren. [...] Heute heißt Königsberg Kaliningrad, und auch der Fluß heißt anders” (Grass 1999: 105); „,W roku 1913 urodził się nasz malarz we wschodniopruskim mieście Królewcu nad rzeką Pregołą. [...] Dzisiaj Królewiec nazywa się Kaliningrad, a i rzeka nosi inne miano" (Grass 2001: 92).

W związku z przekładem nazwy miasta Königsberg pojawia się kolejna wątpliwość, szczególnie wobec skontrastowania tegoż toponimu z dzisiejszą nazwą Kaliningrad. W cytowanym fragmencie zaznaczony jest bowiem wyraźnie punkt widzenia. Nazwa jest wykładnikiem przynależności miasta. Jej zmiana symbolizuje zmianę politycznych, administracyjnych i narodowościowych porządków. Urbonim Königsberg ma od wieków swój polski odpowiednik: Królewiec. Tłumacz, używając polskiej nazwy miasta, jest konsekwentny w swojej strategii. Pytanie tylko, czy słusznie. Czy w tym fragmencie nie należałoby zachować punktu widzenia autora powieści, podkreślić przez użycie nazwy niemieckiej przynależności miasta w owym czasie do Prus Wschodnich? Wydaje mi się, że taka strategia byłaby bardziej odpowiednia, pozwoliłaby też zobaczyć czytelnikowi polskiemu, na czym polegało pisarstwo Grassa jako pielęgnowanie pamięci. Wprowadzona w najbliższym kontekście przez autora nazwa Kaliningrad natomiast znacznie ułatwiłaby czytel- 
nikowi polskiemu poprawną identyfikację miejscowości bez odwoływania się do zewnętrznych źródeł encyklopedycznych ${ }^{9}$.

Analizując nazwy w powieści, osobno należy potraktować okres II wojny światowej. Do niego odnosi się na przykład nazwa Stalingrad, gdy mowa o bitwie pod Stalingradem (Schlacht von Stalingrad - Grass 1999: 111, Grass 2001: 96), którą należy uznać w tym kontekście za neutralną.

Natomiast wyraźnym problemem przekładowym jest tłumaczenie urbonimu Danzig. W czasie II wojny światowej miasto Gdańsk miało tylko jedną nazwę urzędową: Danzig. Grass, który stronę wcześniej - w innym kontekście - używa nazwy polskiej Gdańsk, odnosząc się do czasu kończącej się wojny, pisze:

Und erinnert uns nicht des Kanzlers Sohn, der stets finster und wie vernagelt auf etwas blickt, das nicht das ist, an einen Knaben, der Störtebeker genannt wurde und als Anführer einer Jugendbande die Stadt Danzig und deren Hafengelände unsicher machte? Das war während der Schlußphase des letzten Krieges. Störtebeker und seine Stäuber waren weit über den Reichsgau Westpreußens hin in Verruf. Und war es nicht so, daß der kleine Oskar, als er gerade voll trüber Gedanken die Langfuhrer Herz-Jesu-Kirche verließ, dem Anführer Störtebeker und dessen Bande begegnete? (Grass 1999: 90).

Przekład tego fragmentu brzmi następująco:

A czy syn kanclerza, ponuro i jakby z maniackim uporem wpatrujący się stale w coś, czego nie ma, nie przypomina nam chłopaka, który miał przezwisko Störtebeker i jako przywódca młodocianej bandy stał się postrachem miasta Gdańska i jego terenów portowych? Było to w końcowej fazie ostatniej wojny. Störtebeker i jego Wyciskacze cieszyli się złą sławą daleko poza granicami okręgu Prusy Zachodnie. I czy nie zdarzyło się, że mały Oskar, wyszedłszy właśnie pełen smętnych myśli z wrzeszczańskiego kościoła Serca Jezusowego, spotkał przywódcę Störtebekera i jego bandę? (Grass 2001: 79).

W tym kontekście istotne byłoby zachowanie nazwy Danzig również w przekładzie, gdyż chodzi tutaj nie tylko o identyfikację i lokalizację miasta w przestrzeni, ale ponadto o lokalizację w czasie. Poza tym warto zwrócić uwagę na fakt, iż nazwa okręgu administracyjnego - także odnosząca się do III Rzeszy - jest przetłumaczona niedokładnie, gdyż nazywał się on Okręgiem Rzeszy, a nie po prostu okręgiem $^{10}$. Również ta nazwa lokalizuje w czasie. Natomiast przymiotnik odmiejscowy

9 Warto w tym kontekście zwrócić też uwagę na fakt, iż w wariantach nazewniczych pozostaje ślad zmieniających się zwierzchności, który jest wyraźnie podkreślony w omawianym fragmencie prozy Grassa. Ponadto niektóre nazwy mogą uzyskać status „znaku kulturowego” (Zierhoffer, Zierhofferowa 155), jak właśnie Königsberg czy Królewiec jako miasto Kanta.

10 Por. np. adekwatne użycie nazwy w tytule książki Sylwii Grochowiny Szkolnictwo niemieckie w Okręgu Rzeszy Gdańsk - Prusy Zachodnie w latach 1939-1945 czy hasło w Encyklopedii PWN: „Gdańsk-Prusy 
Langfuhrer ma przede wszystkim funkcję identyfikującą i lokalizującą, więc w tym przypadku przekład za pomocą przymiotnika wrzeszczański jest jak najbardziej adekwatny.

Kolejne dwa passusy odnoszą się także do końca II wojny światowej. Pierwszy $\mathrm{z}$ nich opowiada o Tulli Pokriefke:

Sie roch nach Tischlerleim und war gegen Kriegsende Straßenbahnschaffnerin. Richtig! Die Linie Fünf. Fuhr vom Heeresanger bis rauf zur Weidengasse und zurück. Es hieß: Sie soll mit der 'Gustloff' von Danzig weg und draufgegangen sein (Grass 1999: 91).

Pachniała klejem stolarskim i pod koniec wojny była konduktorką kolejową. Racja! Na trasie piątki. Jeździła z Poligonowej na Łąkową i z powrotem. Mówili, że podobno zabrała się z Gdańska na "Gustloffa” i poszła z nim na dno (Grass 2001: 80).

We fragmencie tym występują dwa hodonimy i jeden urbonim. Położona w dzielnicy Wrzeszcz ulica Heeresanger kilkakrotnie przemianowana po wojnie nosi dziś nazwę ul. Legionów ${ }^{11}$, natomiast Weidengasse to $u l$. Łąkowa. W tym wyimku problemem przekładowym jest ponownie kwestia zachowania punktu widzenia, ale także lokalizacji w czasie i przestrzeni. Użyta przez tłumacza nazwa ulicy Poligonowa nie pozwala na identyfikację topograficzną (trudno powiedzieć nawet, czy tłumacz odwołuje się do nazwy funkcjonującej w Wolnym Mieście Gdańsku, czy może tłumaczy nazwę bez uwzględnienia realiów nazewniczych). Ponadto nazwy niemieckie lokalizują miejscowość w określonym okresie historycznym, kiedy miasto było pod wyłączną administracją III Rzeszy i nie używano polskich nazw. Jednoznacznie pozwalają też zrekonstruować perspektywę jako punkt widzenia Niemca. Co zmienia się w przekładzie? Mamy w nim do czynienia z polskim miastem, widzianym oczyma Polaka, identyfikacja i lokalizacja ulicy jest utrudniona, jeżeli nie niemożliwa. Lepszą strategią przekładową byłaby w tym miejscu, moim zdaniem, reprodukcja niemieckich nazw, tak jak uczynił to Błaut w opisie ulic Berlina, co opisałam powyżej.

Podobną zmianę perspektywy obserwujemy w kolejnym wyimku, gdzie z niemieckiego punktu widzenia opisany jest koniec wojny. Narrator opowiada o ucieczce ludności cywilnej z miasta, które dla uciekinierów ewakuujących się przed nadciągającą Armią Czerwoną, nie nosiło miana Gdańsk, lecz Danzig: „Also sehen wir die brennende Stadt Danzig, Flüchtlingstrecks und die Flucht übers Wasser. [...] Das geschah am dritten Mai, fünf Tage vor Ende des Zwischenkrieges" (Grass 1999: 439); „Widzimy więc płonące miasto Gdańsk, kolumny uciekinierów i uciecz-

Zachodnie, niem. Reichsgau Danzig-Westpreussen, okręg adm. III Rzeszy 1939-45; obejmował Wolne Miasto Gdańsk, kilka powiatów Prus Wschodnich, większość powiatów przedwojennego woj. pomor. i skrawek woj. warsz. [...]".

11 Informacja według Institut der Danziger Straßenkunde (Heeresanger). 
kę po wodzie. [...] Stało się to trzeciego maja, na pięć dni przed końcem międzywojny" (Grass 2001: 374). A zatem i tutaj w przekładzie dochodzi do zmiany punktu widzenia.

Następną grupą toponimów są nazwy odnoszące się do przedwojennego Gdańska i Prus Wschodnich, reprezentujące wyraźnie punkt widzenia byłych mieszkańców, tzw. „wypędzonych". Pierwszy wyimek odnosi się do dzieciństwa Matzeratha i malarza Malskata: "Zwischendurch sprachen beide, wie um Abstand und Anlauf zu nehmen, von ihrer Kindheit. Sie nannten Danzig und Königsberg unvergeßlich” (Grass 1999: 456); „Czasami, jakby dla nabrania dystansu i rozpędu, mówili obaj o swoim dzieciństwie. Nazywali Gdańsk i Królewiec niezapomnianymi" (Grass 2001: 388).

W tym przypadku istotne byłoby zachowanie punktu widzenia przedstawionego w oryginale również w przekładzie, ponieważ występuje tutaj odwołanie do niemieckiej historii miast, do utraconej arkadii dzieciństwa. Sprawa jest może bardziej problematyczna w sytuacji Gdańska, który przed wojną był wolnym miastem o podwójnej, polsko-niemieckiej tożsamości, jednakże poprzez użycie w tym miejscu niemieckiej nazwy Grass odnosi się do Gdańska niemieckiego. Gdy autor ma na myśli polski Gdańsk, stosuje odpowiednio - jak pokazałam wcześniej - polską nazwę.

Kolejną grupą toponimów są nazwy niemieckie odnoszące się czasów postludzkich. Wśród nich występują toponimy z obszaru Gdańska oraz okolic i byłych Prus Wschodnich (głównie Kaszub), reprezentujące neutralny punkt widzenia, o funkcji przede wszystkim identyfikującej i lokalizującej:

Und in jener Stadt, die für dich, unseren Freund, aufgespart in der Raumkapsel, von besonderem Interesse ist, nutzten wir die Kasematten im Hagelsberg, der seit altersher, neben dem Bischofsberg, die Stadt überragt. [...] Auf dem Hagelsberg soll Jagel, ein pruzzischer Fürst und Gott, seinen Sitz gehabt haben. [...] Doch nur ein Teil unserer in Gdańsk und Umgebung ansässigen Völker suchte in Hagelsberg Zuflucht, die Mehrheit grub sich mit Krallen und Zähnen im kaschubischen Hinterland ein. Oben hatten wir vorläufig nichts mehr zu suchen (Grass 1999: 88).

Gdy nazwy pełnią takie funkcje, najważniejsze w przekładzie jest umożliwienie odbiorcy zidentyfikowania i zlokalizowania opisywanych obiektów. Dla czytelnika niezaznajomionego z topografią Gdańska nazwa i polska, i niemiecka będzie brzmiała obco, jednak użycie polskiego odpowiednika znacząco ułatwia polskiemu odbiorcy rozpoznanie i umiejscowienie opisywanych miejsc, co jest w tej scenie najistotniejsze. Dlatego analizowane tłumaczenie w tym wypadku można uznać za jak najbardziej udane:

A w owym mieście, które ciebie, naszego przyjaciela, ocalonego w kapsule kosmicznej, szczególnie interesuje, wykorzystałyśmy kazamaty na Grodzisku, które od dawien 
dawna, obok Biskupiej Górki, wznosi się ponad śródmieściem. [...] Na Grodzisku miał podobno swą siedzibę Jagel, pruski książę i bóg. [...] Ale tylko część naszych stad osiadłych w Gdańsku i okolicy ukryła się w podziemiach Grodziska, większość pazurami i zębami zakopała się na kaszubskim zapleczu (Grass 2001: 77-78).

Szczególną rolę w powieści odgrywają nominacje podwójne. Wielokrotnie obok nazw funkcjonujących obecnie Grass wprowadza do tekstu nazwy dawne, obowiązujące do 1945 roku, co można uznać za sposób kultywowania pamięci. Odnosi się to również do czasów postludzkich: „In Kartuzy, Tczew und Nowy Staw, das vormals Neuteich hieß, haben sie Außenstellen errichtet" (Grass 1999: 445); „W Kartuzach, Tczewie i Nowym Stawie ustanowiły swoje przedstawicielstwa” (Grass 1999: 379). Jak widzimy, tłumacz kolejny raz opuszcza informacje o wcześniejszym nazewnictwie, co będzie widoczne również w następnych przykładach.

Jeżeli chodzi o toponimy podwójne, w powieści występują nazwy niemieckie, obowiązujące do 1945 roku, oraz nazwy polskie, obowiązujące obecnie: „Allerdings wohnt Anna Koljaiczek nich mehr in Bissau-Abbau, sondern mehr nach Mattern hin, das heute Matarnia heißt. Der Bau des neuen Flughafens war Grund dieser Vertreibung” (Grass 1999: 211); „Wszelako Anna Koljaiczkowa nie mieszka już w Bysewie-Wybudowaniu, lecz bardziej w stronę Matarni. Budowa nowego lotniska była przyczyną tego wypędzenia" (Grass 2001: 183). W przytoczonym przekładzie po raz kolejny znika perspektywa niemiecka, element historii miasta. Pozostaje polskie tu i teraz. Nieco inaczej sprawa przedstawia się w następnym przykładzie, w którym nawet w nazwie polskiej, użytej przez Grassa, zaznaczony jest niemiecki punkt widzenia, bo nazwa ulicy (Grunwaldska) jest niedokładna:

Schon fahren sie abermals vom Olivaer Tor durch die Grunwaldska, die seinerzeit Große Allee, später Hindenburgallee hieß, nun durch Langfuhrs Hauptstraße, die ebenfalls mehrmals den Namen wechselte, jetzt links ab Hochstrieß hoch, an den Husaren-, später Schutzpolizei-, dann Wehrmacht-, jetzt Milizkasernen vorbei, bis sie hinter Brentau, in dessen sandiger Friedhofserde seine arme Mama liegt, ins gehügelte Land der Kaschuben kommen (Grass 1999: 285).

W przekładzie tłumacz nie wplata do tekstu wprawdzie nazw niemieckich, ale tłumaczy je syntagmatycznie, dzięki czemu w polskim tekście pozostaje jakikolwiek ślad obcości:

już jadą ponownie od Bramy Oliwskiej Grunwaldzką, która w swoim czasie nazywała się Wielką Aleją, później Aleją Hindenburga, potem główną ulicą Wrzeszcza, która również kilkakrotnie zmieniała nazwę, teraz Strzyżą Górną w lewo, koło koszar huzarów, później policji, potem wermachtu, teraz milicji, aż za Brętowem, w którego piasz- 
czystej ziemi cmentarnej leży jego biedna mama, wjeżdżają w pagórkowatą krainę Kaszub (Grass 2001: 245).

Ponieważ jednak w innym miejscu tłumacz nie przekłada hodonimów, takich jak berlińska nazwa ulicy Kurfürstendamm, to - jak sądzę - zdecydowanie bardziej uzasadnione byłoby pozostawienie w tekście nazw niemieckich, czyli Große Allee i Hindenburgallee.

Następny przykład to jedno z niewielu miejsc powieści, gdzie tłumacz pozostawił niemiecką nazwę $\mathrm{w}$ przekładzie, dzięki czemu wymiar historyczny i refleksja nad zmieniającymi się losami miasta zostały zachowane: „Wenn meine Heimatstadt Danzig, die seit Ende des vorläufig letzten Weltkrieges Gdańsk heißt, das Glück haben sollte, den neutronisierten Städten anzugehören [...]” (Grass 1999: 238); ,"Gdyby moje rodzinne miasto Danzig, które od końca na razie ostatniej wojny światowej nazywa się Gdańsk, miało mieć szczęście należenia do miast przewidzianych do neutronizacji [...]" (Grass 2001: 206).

Podwójne nominacje w niektórych miejscach powieści wskazują również w sposób neutralny na podwójną tożsamość miasta: „Von oben gesehen, will mir Danzig oder Gdańsk wie eine Stadt vorkommen, die sich mit einem Schlammwall gegen das überflutete Werder abgeriegelt hat" (Grass 1999: 326); „,Widziany z góry Danzig bądź Gdańsk wydaje mi się miastem, które odgrodziło się wałem szlamu od zalanych Żuław" (Grass 2001: 279). Jak widzimy, w tym wypadku tłumacz zachował w przekładzie obie nazwy.

Owe podwójne nominacje stają się szczególnie istotne w końcowej części fabuły, kiedy powieść staje się antyutopijną wizją przyszłości. W przekładzie jednak będące miejscem akcji miasto jest tylko miastem polskim, o jednej tożsamości:

Sie haben im Raum Danzig-Gdańsk ein Abgabesystem entwickelt [...] (Grass 1999: 454).

[...] w okręgu gdańskim wprowadziły one system danin, który człekoszczurom gwarantuje pożywienie w nadmiarze, a wszystkim plemionom szczurzym, które uprawiają rolę, własność ziemską (Grass 2001: 387).

Und selbstverständlich werden wir, wie schon die Rattenvölker zuvor, alles tun, um die Bausubstanz der Stadt Danzig-Gdańsk zu erhalten (Grass 1999: 466).

I oczywiście, jak to uczyniły już przedtem szczurze plemiona, zrobimy wszystko, aby zachować kruszącą się substancję budowlaną miasta Gdańsk (Grass 2001: 397).

Wenn sie beiläufig sagt, die Herrschaft der neuschwedischen Watsoncricks im Raum Danzig-Gdańsk erweist sich als milde und kommt ohne Härte aus, spricht sie in eigener Sache (Grass 1999: 461). 
Kiedy mówi mimochodem, że panowanie neoszwedzkich watsoncricków w okręgu gdańskim okazuje się łagodne i obywa się bez surowości, przemawia we własnej sprawie (Grass 2001: 392).

Ostatnią grupą nazw, które chcę omówić, są toponimy będące projekcją przyszłości. W tym wypadku Grass również używa nominacji podwójnych, jednak w jego opowieści zmienia się jeden istotny szczegół, który jest całkowicie niewidoczny w przekładzie polskim, gdyż tłumacz go każdorazowo pominął. Dotychczas autor wprowadzał nazwy niemieckie w porządku uprzedniości: podając polską nazwę, uzupełniał informację o tym, że dana miejscowość wcześniej nazywała się inaczej i wprowadzał nazwę niemiecką. Ewentualnie wprowadzając nazwę niemiecką podawal, że dane miejsce nosi teraz inną nazwę polską. Pod koniec powieści ów porządek ulega odwróceniu. Nazwy niemieckie pojawiają się w porządku następstwa, to znaczy miejsca, które kiedyś nosiły polskie miana, noszą teraz (ponownie) nazwy niemieckie:

[...] der Langen Brücke gegenüber seemännisch einwandfrei anlegte; als unter den Rattenvölkern die Nachricht umlief, die Kommenden hätten an der Speicherinsel, die vormals polnisch Spichlerze geheißen hatte, endgültig festgemacht, da zog es die Ratten aus dem Werft- und Hafengebiet der Jungstadt, von Neufahrwasser und den Schlammdämmen in Strömen zur Alt- und Rechtstadt, durch deren Gassen zum Mottlauhafen, so daß bald nach dem Anlegen des Wracks das Frauen- und Brotbänkertor, das Grüne und das Heiligengeisttor verstopft, alle Uferanlagen von Ratten überschwemmt, die Fenster der gotischen Häuser zur Mottlau hin gepfropft voll und deren Giebel von Rattentrauben behängt waren (Grass 1999: 402).

[...] przybił do brzegu naprzeciwko Długiego Pobrzeża z żeglarskiego punktu widzenia bezbłędnie; kiedy wśród szczurzych plemion rozeszła się wieść, że przybysze zacumowali na dobre na Wyspie Spichlerzy, szczury z terenów stoczniowych i portowych Nowego Miasta, z Nowego Portu i szlamowych grobli pospieszyły strumieniami na Stare i Główne Miasto, ich ulicami do portu na Motławie, tak że wkrótce po przycumowaniu wraku bramy Mariacka i Chlebnicka, Zielona i Św. Ducha były zapchane, wszystkie bulwary nadbrzeżne zalane przez szczury, okna gotyckich kamienic nad Motławą wypełnione do ostatka, a ich szczyty obwieszone szczurzymi winogronami (Grass 2001: 343).

Ten punkt widzenia znika całkowicie w polskim przekładzie, w którym nadal mamy do czynienia tylko z polskimi endonimami. Podobnie w kolejnym przykładzie: „In Neufahrwasser, das früher Novy Port hieß und dessen Wohngebiete bis nach Wrzeszcz unter Schlammwällen liegen [...], bis zur Mole hin: Ratten, überall Ratten [...]” (Grass 1999: 401); „W Nowym Porcie, którego dzielnice mieszkaniowe 
aż po Wrzeszcz spoczywają pod wałami szlamu [...] aż po molo: szczury, wszędzie szczury [...]" (Grass 2001: 342).

W czasach postludzkich konflikty rozgrywają się już nie między ludźmi, a między szczurami, które jednak bardzo ludzi przypominają. Wszystkie stereotypy, które wzajemnie przypisują sobie Niemcy i Polacy, odnaleźć można i w świecie szczurów. Polskie szczury troszczą się o zabytki, niemieckie kochają porządek, polskie potrafią wspaniale improwizować, a niemieckie uzurpują sobie prawo do Gdańska: "Sie aber reden besitzergreifend von unserem Danzig” (Grass 1999: 366); „A one uzurpatorsko mówią o naszym Danzigu" (Grass 2001: 313). To jeden z nielicznych przypadków, gdzie tłumacz, słusznie, pozostawia w przekładzie nazwę Danzig.

Ostatecznie w Gdańsku zostają same szczury. Miasto jednak rozpada się kawałek po kawałku:

Das alte Danzig jedoch zerfällt. Es bröckeln die reichgeschmückten Fassaden. Türme stürzen geborsten. Gotische Giebel neigen sich, kippen weg. Langsamer Verfall, jeder Backstein, Sankt Marien, alle Kirchen geben sich auf (Grass 1999: 486).

Stary Gdańsk jednak się rozpada. Kruszą się bogato zdobione fasady. Wieże walą się popękane. Gotyckie szczyty chylą się, odpadają. Powolna ruina, każda wypalana cegła, Maria Panna, wszystkie kościoły dają za wygraną (Grass 2001: 414).

Gdańsk? A może jednak Danzig?

\section{Wnioski}

Podsumowując produkcję Matzeratha, narrator powieści wypowiada następujące słowa:

Ich gebe zu, daß dieser Teil der Matzerathschen Videoproduktion Längen aufweist. Schließlich sind uns filmische Katastrophenauswertungen aus vielen, während der Schlußphase gängigen Kinofilmen bekannt. [...]. Dennoch unterscheidet sich Matzerathsche Schöpfung, trotz der genannten Mängel, von üblichen Endzeitprodukten. Ihr Vorgriff auf fürsorglich geplantes Nachleben beweist Perspektive (Grass 1999: 443).

Przyznaję, że ta część Matzerathowego dzieła ma dłużyzny. Ostatecznie katastroficzne wizje są nam znane $\mathrm{z}$ wielu popularnych $\mathrm{w}$ końcowej fazie filmów kinowych. [...] Jednakże film Matzeratha, mimo wspomnianych niedostatków, różni się od ogółu katastroficznych produktów. Jego antycypacja starannie zaplanowanego życia to coś, co ma perspektywę (Grass 2001: 378). 
Cytat można potraktować jako swoisty autokomentarz Grassa. Jak starałam się pokazać, punkt widzenia to coś, co w powieści Grassa jest niezmiernie ważne. Niestety owa perspektywa zmienia się całkowicie w przekładzie, na co wpływ mają między innymi opuszczenia onomastycznych odniesień do niemieckiej historii miasta i regionu.

Błaut, decydując się na używanie zasadniczo tylko polskich toponimów w odniesieniu do Gdańska (z nielicznymi wyjątkami, o których pisałam powyżej), zmienia wydźwięk utworu, przez co wpływa też w sposób istotny, jak sądzę, na recepcję utworu w Polsce. Gdzie Grass świadomie różnicuje i niuansuje, tam Błaut ujednolica, wymazując na poziomie nazewnictwa ślady niemieckiej bytności w Gdańsku, niemieckiej historii miasta. To, co Grass pragnie przypomnieć, uprawiając pamięć, to Błaut skazuje na ponowne zapomnienie.

Conrad, która „wyrusza zwiedzać krajobraz, który już dawno wszedł do kanonu literatury światowej" (tłum. J.K.), opisując wizytę w Gdańsku, podczas której podąża śladami Blaszanego Bębenka, konstatuje: „Noch ist kein einziger polnischer Ortsname gefallen. Andreas Kasperski führt durch Danzig, als wäre es eine deutsche Stadt" (,Jeszcze nie padła żadna polska nazwa. Andreas Kasperski oprowadza po Gdańsku, jak gdyby było to niemieckie miasto", tłum. J.K.).

Sławomir Błaut wręcz odwrotnie: opowiada Szczurzyce, jak gdyby była to opowieść o zawsze polskim mieście. Czy to jeszcze opowieść Grassa? Czy to jeszcze jego sen? Czy to jeszcze jego marzenie?

\section{BIBLIOGRAFIA}

Burdziej, Bogdan. Super flumina Babylonis: Psalm 136(137) w literaturze polskiej XIX-XX w. Toruń: Uniwersytet Mikołaja Kopernika, 1999.

Conrad, Bernadette. “Danzig: Oskars Heimat”. Die Zeit 46 (2008). Web. 02.11.2016.

Cywiński, Piotr. „Polskie gęganie po niemiecku - nazewnictwo jest najkrótszą i najszybciej zapadającą w pamięć lekcją historii". 2013. Web. 02.11.2016. <http://wpolityce.pl/polityka/152238-polskiegeganie-po-niemiecku-nazewnictwo-jest-najkrotsza-i-najszybciej-zapadajaca-w-pamiec-lekcja-historii>

Czerny, Andrzej. Teoria nazw geograficznych. Warszawa: PAN IGiPZ, 2011.

Gajda, Stanisław. „Narodowokulturowy składnik znaczenia nazw własnych w aspekcie edukacyjnym”. Nazwy własne w jezzyku, kulturze i komunikacji społecznej. Red. R. Mrózek. Katowice: Wydawnictwo Uniwersytetu Śląskiego, 2004. S. 21-28.

"Gdańsk - Prusy Zachodnie". Web. 7.02.2018. <https://encyklopedia.pwn.pl/haslo/Gdansk-Prusy-Zachodnie;3904551.html>

Grass, Günter. Die Rättin. Darmstadt/Neuwied: dtv, 1999.

Grass, Günter. Szczurzyca. Przeł. Sławomir Błaut. Gdańsk: Wydawnictwo Oskar, 2001. 
Gruettner, Mark M. Intertextualität und Zeitkritik in Günter Grass' Kopfgeburten und Die Rättin. Tübingen: Stauffenburg-Verlag, 1997.

Hejwowski, Krzysztof. „Nazwy własne w tekście literackim - techniki tłumaczenia”. Przekład. Jezyk. Kultura. T. 3. Red. R. Lewicki. Lublin: Wydawnictwo UMCS, 2012. S. 11-22.

„Heeresanger". Web. 12.11.2016. <http:// danzig.at/index.php?id=48,1037,0,0,1,0>

Kubaszczyk, Joanna. „Zur Übersetzung von Toponymen im Kontext der Übersetzungsbewertung”. Translation Landscapes - Internationale Schriften zur Übersetzungswissenschaft. T. 1. Red. P. Sulikowski, A. Sulikowska, E. Lesner. Hamburg: Verlag Dr. Kovač, 2017. S. 125-137.

Makarski, Władysław. „Przestrzeń w Panu Tadeuszu”. Web. 7.02.2018. <http://paris.pan.pl/pl/images/stories/pliki/PDF/Roczniki/R7/makarski.pdf>

Wolin. Web. 7.02.2018. <http://encyklopedia.pwn.pl/haslo/Wolin;3997713.html>

Zierhoffer Karol, Zierhofferowa Zofia. „Współczesne polskie nazwy z obszaru Europy i ich kontekst kulturowy". Nazwy własne w jezzyku, kulturze i komunikacji społecznej. Red. R. Mrózek. Katowice: Wydawnictwo Uniwersytetu Śląskiego, 2004. S. 141-156.

Ziomek, Jerzy. „Przekład - rozumienie - interpretacja”. Polska myśl przekładoznawcza. Antologia. Red. M. Heydel, P. de Bończa Bukowski. Kraków: Wydawnictwo Uniwersytetu Jagiellońskiego, 2013. S. 163-192. 